\title{
Need of Neonatal Sepsis Surveillance in India
}

\section{Deepak Chawla $^{1}$}

Received: 11 March 2020 / Accepted: 20 March 2020 /Published online: 1 April 2020

(C) Dr. K C Chaudhuri Foundation 2020

Systemic infections are the second most common direct cause of neonatal mortality [1]. Sepsis and meningitis also contribute to neonatal deaths due to other direct causes like prematurity, birth asphyxia, and congenital malformations. Hospital-acquired infection (HAI) is a common complication during care of preterm or sick neonates in neonatal units, and is associated with high case-fatality rate, prolonged hospitalization, use of higher generation antibiotics, and adverse neurological outcome [2, 3]. Yet, most neonatal units in low- and middle-income countries may lack a formal monitoring mechanism or systematic strategic response to contain HAIs [4]. In this issue of the journal, Balachander et al. present successful implementation of a quality improvement project targeted at monitoring and containment of infection outbreaks [5]. The study highlights the importance of following a systematic approach for detection and control of an infection outbreak. Important steps followed in the study included 1) surveillance by case definition and listing, 2) cohorting of infected and colonized cases, 3) identification of source of infection and 4) strengthening of infection control practices.

Deepak Chawla

drdeepakchawla@gmail.com

1 Department of Neonatology, Government Medical College Hospital, Chandigarh 160 030, India
Foremost step in the outbreak control is timely identification of increase in the incidence of infection with a specific microorganism. A visual display of infectionrelated quality metrics on a dashboard can be a useful tool to monitor the incidence and inform quality improvement initiatives [6]. Table 1 presents a list of variables which can be displayed with such a tool. These variables can be easily collected as part of the census reports. Visual display in the form of a run or control chart and regular review assists in detection of any trends or shifts in the incidence of HAI. For a unit with no previous data, a baseline incidence data will need to be collected over 9-12 mo to get information about natural variation in the incidence. In addition to monitoring for incidence of HAI, the unit also needs to monitor for growth of methicillin-resistant Staphylococcus aureus, multi-drug resistant Gramnegative bacteria and vancomycin resistant Enterococcus. Growth of any of these organisms should be responded to by looking for source of infection, including patients and fomites/equipment colonized by the index bacteria. 
Table 1 Monitoring infections in a neonatal unit

\begin{tabular}{|c|c|c|c|}
\hline Metric & Purpose & Definition & Method of display \\
\hline Number of neonates admitted & To define denominator & Number of neonates admitted & $\begin{array}{l}\text { Not displayed (used for calculation } \\
\text { of other metrics) }\end{array}$ \\
\hline $\begin{array}{l}\text { Number of neonates on } \\
\text { respiratory support }\end{array}$ & To define denominator & Number of neonates admitted & $\begin{array}{l}\text { Not displayed (used for calculation } \\
\text { of other metrics) }\end{array}$ \\
\hline $\begin{array}{l}\text { Number of neonates with a } \\
\text { central line }\end{array}$ & To define denominator & Number of neonates admitted & $\begin{array}{l}\text { Not displayed (used for calculation } \\
\text { of other metrics) }\end{array}$ \\
\hline $\begin{array}{l}\text { Number of neonates with } \\
\text { proven hospital-acquired } \\
\text { sepsis }\end{array}$ & Main outcome indicator & $\begin{array}{l}\text { Number of neonates with positive blood, } \\
\text { CSF or urine culture per } 1000 \text { baby days, } \\
\text { per } 1000 \text { respiratory support days and } \\
\text { per } 1000 \text { central line days }\end{array}$ & Control chart \\
\hline $\begin{array}{l}\text { Number of neonates on } \\
\text { higher-generation antibiotics }\end{array}$ & Outcome indicator & $\begin{array}{l}\text { Number of neonates receiving higher } \\
\text { generation antibiotics (e.g., meropenem, } \\
\text { colistin, vancomycin) per } 1000 \text { baby } \\
\text { days }\end{array}$ & Control chart \\
\hline $\begin{array}{l}\text { Number of neonates with } \\
\text { ventilator associated } \\
\text { pneumonia (VAP) }\end{array}$ & Outcome indicator & $\begin{array}{l}\text { Number of neonates who develop VAP per } \\
1000 \text { respiratory support days }\end{array}$ & Control chart \\
\hline
\end{tabular}

CSF Cerebrospinal fluid

\section{Compliance with Ethical Standards}

\author{
Conflict of Interest None.
}

\section{References}

1. GBD 2015 Maternal Mortality Collaborators. Global, regional, and national levels of maternal mortality, 1990-2015: a systematic analysis for the Global Burden of Disease Study 2015. Lancet. 2016;388: $1775-812$.

2. Cai S, Thompson DK, Anderson PJ, Yang JY-M. Short- and longterm neurodevelopmental outcomes of very preterm infants with neonatal sepsis: a systematic review and meta-analysis. Children. 2019;6:131.
3. Shane AL, Sánchez PJ, Stoll BJ. Neonatal sepsis. Lancet. 2017;390: 1770-80.

4. Chaurasia S, Sivanandan S, Agarwal R, Ellis S, Sharland M, Sankar MJ. Neonatal sepsis in South Asia: huge burden and spiralling antimicrobial resistance. BMJ. 2019;364:k5314.

5. Balachander B, Rajesh D, Pinhero CL, Paul S, Stevens S, Rao S. Response measures to infection outbreaks during the second year of sustenance phase of infection control quality improvement. Indian J Pediatr [Internet]. 2020. Available at: https://doi.org/10.1007/ s12098-020-03201-6. Accessed 10 March 2020.

6. Ivers NM, Barrett J. Using report cards and dashboards to drive quality improvement: lessons learnt and lessons still to learn. BMJ Qual Saf. 2018;27:417-20.

Publisher's Note Springer Nature remains neutral with regard to jurisdictional claims in published maps and institutional affiliations. 